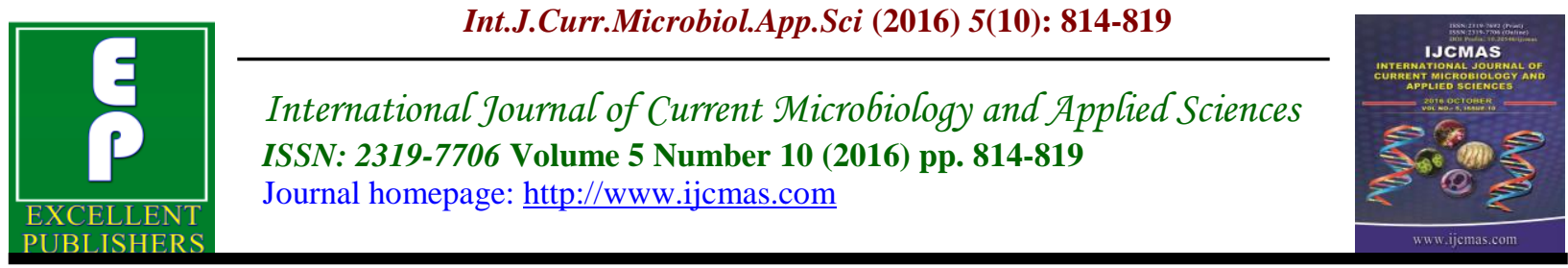

Original Research Article

http://dx.doi.org/10.20546/ijcmas.2016.510.088

\title{
Antibacterial Activity on Medicinal Herbs
}

\author{
C. Vishaalini ${ }^{1 *}$, N. Hema Shenpagam ${ }^{2}$ and Lali Growther ${ }^{3}$ \\ Department of Microbiology, Hindusthan College of Arts and Science, Coimbatore, India \\ *Corresponding author
}

Keywords

Alapina calcarata and Andrographis paniculate, Antibacterial Activity

Article Info

Accepted:

25 September 2016

Available Online:

10 October 2016

\section{A B S T R A C T}

Medicinal plants are gaining much interest recently, because they used to treat respiratory tract infections. The study on medicinal plants started with extraction procedures. Aqueous, Methanolic and Ethanolic extracts of the eight most popular plants, Alpina calcarata, Andrographis paniculate, Justic adhatoda, Solanum trilobatum, Zingiber officinalis, Pipper longum, Solanum xanthocarpum, Piper nigrum. The extracts of those plants were concentrated by rotary evaporator, and these concentrated samples were subjected to invivo antibacterial assay against three human pathogenic Staphylococcus aureus, Streptoccous sps, and Pseudomonas sps. The efficacy of the samples was tested by bio assay method using the disc diffusion test. Zone of inhibition of the extracts were compared with the standard Ampicillin. The results showed that, the remarkable inhibition of the bacterial growth was shown against the tested organisms in methanolic extraction mainly Alapina calcarata and Andrographis paniculate.

\section{Introduction}

Herbs are natural remedies for the infectious disease with higher safety profile and efficacy. Herbs used as a traditional medicine, because it contain wide range of substances that can be used to treat chronic disease (Duraipandiyan et al., 2006). Various medicinal plants have been used for years to treat disease all over the world. So herbs have been used as a source of medicine (Farombi, 2003). Now a days there are many drugs which was used in clinical were discovered from the plants, were used in traditional communities. (Van Wyk et al., 2002). Medicinal plants are widely used by all sections of the population either directly or indirectly in the preparation of modern pharmaceuticals (Karthikeyan, 2000; Dubey et al., 2004). Traditional medicine recently gives the fastest growth in medicinal field with herbal therapies. This mode of treatment is widely used because it is considered as more acceptable, accessible, histolic and low cost and it also proven to be safe (Gessler, 1995).

The older generation is slowly dying who has the knowledge of medicinal plants which contain bioactive agent, because the knowledge of medicinal plants and the methods of processing of the crude drugs are only available in the rural communities and only perpetuated by word of mouth and 
within families and small communities. Younger people on the other hand who now have taken up formal education rarely get interested in traditional lifestyles. By the advantage of the active components which present in herbal remedies used to combined with many other substances that appear to be inactive. These complementary components give the safety and efficiency to the whole plant and much superior to that of its isolated and pure active components (Shariff, 2001).

The effects of plant extracts on bacteria by antibacterial method have been studied by a number of researchers in the world (Reddy et al., 2001; Urul, 2002; Ateb and Urul, 2003). Antibacterial properties of plants has resulted in current problems which is associated with the use of antibiotics (Shiota et al., 2004; Abu-Shanab et al., 2004).The research on the medicinal plants should be extended with the identification of the active principles in the plants. Scientific examination of the herbal remedies could leads to the standardization and quality control of the products to ensure their safety.

Medicinal plants (Alpina calcarata, Andrographis paniculate, Justic adhatoda, Solanum trilobatum, Zingiber officinalis, Pipper longum, Solanum xanthocarpum, Piper nigrum) are collected either randomly in geographical areas where the plants are found. Initial screening of plants for possible antibacterial activities typically begins by using various organic extraction methods. The aromatic or saturated organic compounds, which present in the plants are active against micro organism, they are often obtained through initial ethanol or methanol extraction (Vilegs et al., 1997. Those plants were evaluated for the preliminary antibacterial activity. The different extracts of plants were screened for antibacterial activity against some medically important bacterial strains which cause infections in respiratory tract. Drugs which is derived from natural sources are play a significant role in the prevention and treatment of human diseases (Farnsworth., 1993, Houghton., 1995). The screening of plant extracts for antibacterial activity has shown that the higher plants represent a potential source of novel antibiotic prototypes (Afolayan, 2003). Numerous studies have identified the compounds which present in the herbal plants are effective antibiotics (Basile et al., 2000).

\section{Materials and Methods}

The plant material was collected from geographical area where the plant present. The leaves of the plants was withdrawn and dried carefully under shade and then homogenized to fine powder and stored in airtight bottles.

\section{Aqueous Extracts}

Approximately $50 \mathrm{~g}$ of dried and ground plant materials was successively extracted by maceration with water. These extracts were concentrated by freeze dried and stored at $4{ }^{\circ} \mathrm{C}$ until use. (Virgilio Bocanegra-García, 2009).

\section{Organic solvent extraction}

The $50 \mathrm{~g}$ portions of each dried powdered plant part material was soaked separately in $250 \mathrm{ml}$ ethanol and methanol. The extraction was carried out by maceration for 7 days in each solvent at room temperature $\left(25 \pm 2^{\circ} \mathrm{C}\right)$. The solvents extracted material was filtered in separate flaks (Rawlins and Tindall, 1977). All extracts were then dried in a vacuum rotary evaporator, weighed and stored at $4^{\circ} \mathrm{C}$ until further analysis.

\section{Preparation of dilution}

The dried aqueous, methanol, and ethanol extracts were dissolved in their respective 
solvents. For aqueous extracts distilled water and for organic extracts, DMSO was used as a solvent in a proportion of $100 \mathrm{mg} / \mathrm{ml}$. The antibiotic Ampicillin was used at the concentration of $100 \mu \mathrm{g} / \mathrm{ml}$ (Virgilio Bocanegra-García et al., 2009; Muhammad Altaf Hussain et al., 2011.

\section{Microorganisms}

In the present study gram positive bacteria namely Staphylococcus aureus, Streptococcus sps whereas gram negative bacteria like Pseudomonas sps, were used to evaluate the antibacterial potential of different extracts of the selected plant parts.

\section{Antibacterial assay}

A $24 \mathrm{~h}$ old culture of each bacterium was used as an inoculum for the test. The slants were prepared in test tube. The nutrient agar medium was used for bacterial growth. A disc diffusion method was used to assess the presence of antibacterial activities in aqueous and organic extracts of the different plants. Agar well diffusion method is done to detect the antibacterial activity (Tagg and Mengiven, 1971; Stainer et al., 1986). About $15-20 \mathrm{ml}$ of Muller-Hinton agar medium was poured in the sterilized petridish and allowed for solidifying. One drop of bacterial cultures like Staphylococcus aures, Streptococcus sps, Pseudomonas sps was inoculated by swabbing with sterile swab over the MHA plates. Then wells were prepared to load different concentration like $25,50,75,100 \mu 1$ of medicinal plants extract. DMSO and the standard antibiotic ampicillin served as a control. The plates were allowed to stand at room temperature for 30 minutes and incubated in upright position at $37^{\circ} \mathrm{C}$ for 24 hours. The diameters of the zone of inhibition were measured with a ruler. The measurement is recorded (Quinto et al., 2005 and Perez et al., 1990 and Akinyemi et al., 2005).

\section{Results and Discussion}

Plant extracts have been studied against bacteria extensively in the last three decades. Plants have provided a source of inspiration for novel drug components towards human health. A lot of antibacterial screening evaluations published for traditional use in China, Africa and Asia (Nishibe et al., 1982; Vlientinck et al., 1995; Perez and Anesini, 1994; Macfoy and Cline, 1990; Maikere et al., 1989; Forestiere et al., 1988). Unani and Ayurvedic system of medicines are the base of natural blueprint for the development of drugs (Didry et al., 1988).

Subsequent isolation of botanical compounds from plant material is largely dependent on the type of solvent used in the extraction procedure. In olden days water was used as a primary solvent (Jigna parekh, and Sumitra Chanda, 2007). In this study antibacterial activity on methanol extracts of Alapina calacarata and Andrographis paniculate, shows higher efficiency than alcohol and water extracts, to fight against bacterial strains which cause respiratory tract infections especially Streptococcus sps, when compared to Justic adhatoda, Solanum trilobatum, Zingiber officinalis, Pipper longum, Solanum xanthocarpum and Piper nigrum.

The antibacterial activity of methanollic extract of different medicinal herbs namely Alapina calcarata, Andrographis paniculate, Justic adhatoda, Solanum trilobatum, Zingiber officinalis, Pipper longum, Solanum xanthocarpum, Piper nigrum were tested against respiratory tract infections causing pathogens like Staphylococcus aureus, Streptococcus sps, Pseudomonas sps. 
Table.1 Antibacterial Activity of Medicinal herbs in methanol extract Table-1 (Zone of inhibition in $\mathrm{mm}$ )

\begin{tabular}{|l|c|c|c|}
\hline \multicolumn{1}{|c|}{ Plant } & Staphylococcus aureus & Streptococcus sps & Pseudomonas.sps \\
\hline Alpina calcarata & 17 & $\mathbf{1 8}$ & 16 \\
\hline Andrographispaniculata & 15 & $\mathbf{1 7}$ & 15 \\
\hline Justica adhatoda & 12 & 12 & 10 \\
\hline Solanum trilobatum & 15 & 15 & 14 \\
\hline Zingiber officinale & 15 & 15 & 16 \\
\hline Piper longum & 15 & 12 & 13 \\
\hline Solanum xanthocarpum & 10 & 15 & 12 \\
\hline Piper nigrum & 13 & 15 & 13 \\
\hline Ampicillin & 25 & 27 & 20 \\
\hline
\end{tabular}

Table.2 Antibacterial Activity of Medicinal herbs in alcohol extract

Table-2 (Zone of inhibition in $\mathrm{mm}$ )

\begin{tabular}{|l|c|c|c|}
\hline \multicolumn{1}{|c|}{ Plant } & Staphylococcus aureus & Streptococcus sps & Pseudomonas sps \\
\hline Alapina calcarata & 7 & $\mathbf{9}$ & 7 \\
\hline Andrographispaniculata & 7 & $\mathbf{8}$ & 7 \\
\hline Justica adhatoda & 6 & 7 & 5 \\
\hline Solanum trilobatum & 5 & 7 & 4 \\
\hline Zingiber officinale & 4 & 7 & 2 \\
\hline Piper longum & 6 & 7 & 3 \\
\hline Solanum xanthocarpum & 3 & 5 & 2 \\
\hline Piper nigrum & 5 & 7 & 5 \\
\hline Ampicillin & 25 & 27 & 20 \\
\hline
\end{tabular}

Table.3 Antibacterial Activity of Medicinal herbs in aqueous extract

Table-3 (Zone of inhibition in $\mathrm{mm}$ )

\begin{tabular}{|l|c|c|c|}
\hline \multicolumn{1}{|c|}{ Plant } & Staphylococcus aureus & Streptococcus sps & Pseudomonas sps \\
\hline Alapina calcarata & 8 & $\mathbf{9}$ & 7 \\
\hline Andrographispaniculata & 8 & $\mathbf{9}$ & 8 \\
\hline Justica adhatoda & 5 & 7 & 5 \\
\hline Solanum trilobatum & 3 & 3 & 7 \\
\hline Zingiber officinale & 7 & 3 & 3 \\
\hline Piper longum & 9 & 11 & 9 \\
\hline Solanum xanthocarpum & 4 & 6 & 4 \\
\hline Piper nigrum & 4 & 6 & 3 \\
\hline Ampicillin & 25 & 27 & 20 \\
\hline
\end{tabular}


In this Alpina calcarata and Andrographis paniculata gives the high zone of inhibition against Streptococcus sps. (Table.1)

The antibacterial activity of alchollic extract of different medicinal herbs namely Alapina calcarata, Andrographis paniculate, Justic adhatoda, Solanum trilobatum, Zingiber officinalis, Pipper longum, Solanum xanthocarpum, Piper nigrum were tested against respiratory tract infections causing pathogens like Staphylococcus aureus, Streptococcus sps, Pseudomonas sps. In this Alpina calcarata and Andrographis paniculata gives the high zone of inhibition against Streptococcus sps. (Table.2)

The antibacterial activity of aqueous extract of different medicinal herbs namely Alapina calcarata, Andrographis paniculate, Justic adhatoda, Solanum trilobatum, Zingiber officinalis, Pipper longum, Solanum xanthocarpum, Piper nigrum were tested against respiratory tract infections causing pathogens like Staphylococcus aureus, Streptococcus sps, Pseudomonas sps. In this Alpina calcarata and Andrographis paniculata gives the high zone of inhibition against Streptococcus sps. (Table.3).

\section{References}

Abu-Shanab, B., Adwan, G. and AbuSafiya, D. 2004. Antibacterial activities of some plant extract utilized in Palestine in popular medicine. Turk. J. Biol., 28: 99-102.

Afolayan, A.J. 2003 :Extracts from the shoots of Arctotis artotoides inhibit the growth of bacteria and fungi. Pharm. Biol. 41: 22-25.

Akerele, O. 1990. Medicinal Plants in Traditional Medicine. In: Farnsworth, N.R. and Wagner, H. eds.. Econ. Med. Plant Res., Vol.4. Plants and
Traditional Medicine. Academic Press Ltd., London.

Ateb, D.A., Erdo, U.O.T. 2003. Antimicrobial activities of various medicinal and commercial plant extracts. Turk. J. Biol., 27: 157-162.

Basile, A., Sorbo, S., Giordano, S., Ricciardi, L., Ferrara, S., Montesano, D., Castaldo Cobianchi, R., Vuotto, M.L., Ferrara, L. 2000. Antibacterial and Allelopathic activity of extract from Castanea sativa leaves. Fitoterapia, 71: 110-116.

Didry, N., Dubreuil, L., Trotin, F., Pinkas, M. 1998. Antimicrobial activity of the aerial parts of Drosera pellata smith on oral bacteria. J. Ethnopharmacol., 60: 91-96.

Dubey, N.K., Kumar, R. and Tripathi, P. 2004. Globalpromotion of herbal medicine: India's opportunity, Curr Med., 86: 37-41.

Duraipandiyan, V., Ayyanar, M. and Ignacimuthu, S. 2006. Antimicrobial activity of some ethnomedicinal plants used by Paliyar tribe from Tamil Nadu, India. BMC Complementary Altern. Med., 6: 35-41.

Farnsworth, N.R. 1990. The role of ethno pharmacology in drug development. In Chadwick \& Marsh eds.. Bioactive compounds from plants. John Wiley \& Sons, NY..

Farombi, E.O. 2003. African indigenous plants with chemotherapeutic potentials and biotechnological approach to the production of bioactive prophylactic agents. Afr. J. Biotech., 2: 662-671.

Forestiere, A.M., Pizzimenti, F.C., Monforte, T.M. and Bisignano, G. 1988. Antibacterial activity of some African medicinal plants. Pharmacol. Res. Commun., 20(5): 33-36.

Gessler, M. 1995. The Anti malarial potential of medicinal plants 
traditionally used in Tanzania, and their use in the treatment of malaria by traditional healers. Inaugural dissertation, Baseler-Schnelldruck, Basel.

Jigna Parekh and Sumitra Chanda. Phyochemical, Pharmacological and Microbiological Laboratory, Department of Biosciences, Saurashtra University, Rajkot - 360 005, India.

Karthikeyen, S. 2000. A statistical analysis of flowering plants of india,In:Flora of India, Introductry volume part II, NP Singh, DK Singh, PK Hajra and BD Sharma Eds. Botanical Survey of India, Calcutta, pp.201-217

Macfoy, C.A., Anesini, E.I. 1990. In vitroantimicrobial activity of the plants used in traditional medicine in traditional medicine in Sierra Loeone. J. Ethanopharmacol., 28: 323-327.

Maikere, F.R., Puyvelde, L.V., Mutwewingabo, A., Habiyaremye, F.X. 1989. Study of Rwandese medicinal plants used in the treatment of diarrhea. J. Ethnophamacol., 26: 101-109.

Muhammad Altaf Hussain, Muhammad Qayyum Khan, Nazar Hussain and Tariq Habib. 2011. Department of Botany, University of Azad Jammu and Kashmir Muzaffarabad-13100, Pakistan.

Nishibe, S., Okabe, K., Tsukamoto, H., Sakushima, A., Hisada, S., Baba, H.,
Akisada, T. 1982. Studies on the Chinese crude drug Forsythia fructus. The structure and antimicrobial activity of suspensaside isolated from Forsythia suspense. Chem. Pharm. Bull., 30: 4548-4553.

Perez, C., Anesini, C. 1994. In vitro antibacterial activity of Argentine folk medicinal plants against Salmonella typhae. J. Ethnopharmacol., 44: 4146.

Rawlins, E.A., Tindall, B. 1977. Bently's Text Book of pharmaceutics $8^{\text {th }}$ edition, London, pp. 174-198.

Reddy, P.S., Jamil, K., Madhusudhan, P. 2001. Antibacterial activity of isolates from Piper longum and Taxus baccata. Pharm. Biol., 39: 236-238.

Shiota, S., Shimizu, M and Sugiyama, J. 2004. Mechanism of action of corilagian and tellimagrandin I that remarkably potentiate the activity of beta-lactams against Methicillinresistant Staphylococcus aureus. Microbial. Immunol., 48: 67-73.

van Wyk, B.V., Oudtshoorn, B.V. and Gericke, N. 2002. Medicinal plants of South Africa. Briza publications, Pretoria.

Vlietinck, A.J., Hoof, L.V., Tott, J. 1995. Screening of hundred Rwandese medicinal plants for antimicrobial and antiviral properties. $J$. Ethnopaharmacol., 46: 31-47.

\section{How to cite this article:}

Vishaalini, C., N. Hema Shenpagam and Lali Growther. 2016. Antibacterial Activity on Medicinal Herbs. Int.J.Curr.Microbiol.App.Sci. 5(10): 814-819. doi: http://dx.doi.org/10.20546/ijcmas.2016.510.088 